\title{
Immunolocalization of angiotensin-(1-7), angiotensin II and angiotensin- converting enzyme 2 in goat ovary
}

\author{
Imunolocalização de angiotensina-(1-7), angiotensina II e \\ enzima-conversora de angiotensina 2 em ovário de cabras
}

\author{
Lauro César Soares Feitosa ${ }^{1}$ (1), Alécio Matos Pereira² (1), Adeline Andrade Carvalho ${ }^{1}$ (1), \\ Antônio de Sousa Junior ${ }^{1}$ (1), Kinulpe Honorato-Sampaio ${ }^{3}$ (1), Amilton Paulo Raposo Costa ${ }^{{ }^{*}}$
}

\begin{abstract}
There is increasing evidence as to the participation of the ovarian renin-angiotensin system in important reproductive processes. The inhibition of the angiotensin-converting enzyme (ACE) caused an increase in the rate of ovulation and pregnancy in the artificial insemination protocol has fixed time (TFIA). This study aimed to investigate the presence and location of Ang II, Ang- (1-7) and ACE2 in goat ovaries and the possibility of the involvement of these peptides in previous results. Ten ovaries from goats were collected in a slaughterhouse, washed in buffered PBS, perfused with protease inhibitor solution and processed for immunohistochemistry protocol. The search for peptides was performed using the avidin-biotinperoxidase method. A strong immunoreactivity for Ang II in theca cells of antral follicles and corpus luteum was observed. Antral follicles (theca cells), corpus luteum and oocyte cytoplasm in early antral follicles exhibited strong immunoreactivity for Ang-(1-7). There was strong immunoreactivity for ACE2 in the cytoplasm of luteal cells and theca cells of antral follicles. In this study, for the first time, the presence and location of Ang II, Ang-(1-7) and ACE2 are reported in goat ovary, suggesting that there is participation in follicular development, oocyte maturation and corpus luteum development.
\end{abstract}

KEYWORDS: ACE2; Immunohistochemistry; Follicle; Granulosa cell, Corpus luteum; Theca cell.

\begin{abstract}
RESUMO: Há evidências crescentes quanto à participação do sistema renina-angiotensina ovariano em processos reprodutivos importantes. A inibição da enzima conversora de angiotensina (ECA) ocasionou aumento na taxa de ovulação e gravidez no protocolo de inseminação artificial por tempo fixo (TFIA). Este estudo teve como objetivo investigar a presença e localização de Ang II, Ang-(1-7) e ECA2 em ovários de cabras e a possibilidade do envolvimento desses peptídeos em resultados anteriores. Dez ovários de cabras foram coletados em abatedouro, lavados em PBS tamponado, perfundidos com soluçáo inibidora de protease e processados para protocolo de imunohistoquímica. A busca por peptídeos foi realizada usando o método avidina-biotina-peroxidase. Foi observada uma forte imunorreatividade para Ang II em células da teca de folículos antrais e corpo lúteo. Os folículos antrais (células da teca), corpo lúteo e citoplasma do oócito nos folículos antrais iniciais exibiram forte imunorreatividade para Ang-(1-7). Houve forte imunorreatividade para ECA2 no citoplasma das células luteais e células da teca dos folículos antrais. Neste estudo, pela primeira vez, a presença e localização de Ang II, Ang- (1-7) e ECA2 são relatadas em ovário caprino, sugerindo que há participação no desenvolvimento folicular, maturação oocitária e desenvolvimento do corpo lúteo.
\end{abstract}

PALAVRAS-CHAVE: ECA2; Imunohistoquímica; Folículo; Células da granulosa; Corpo lúteo; Células da teca.

\section{INTRODUCTION}

From the discovery of renin to the present days, with the discovery of new components, the renin-angiotensin system (RAS) has been recognized as a regulator of various functions of the animal organism, with emphasis on electrolytic and blood pressure control. In addition, a local
RAS has been described in several organs, such as human heart (ALDERMAN, 2004), human liver (GRACE et al., 2012) and the reproductive system of different species like mouse and rabbit (COSTA et al., 2003; VIANA et al., 2011), but not in goats. Several studies have showed that RAS ovarian influences reproductive functions such as the

\footnotetext{
UUniversidade Federal do Piauí, Teresina/PI, Brasil 
development of the corpus luteum (KOBAYASHI et al. 2002), ovulation (VIANA et al., 2011) and oocyte maturation (HONORATO-SAMPAIO, 2012).

Based on this knowledge, mainly because inhibition of the angiotensin-converting enzyme (ACE) increases the bioavailability of Ang- (1-7) (CHAPPELL et al., 1998), an experiment showed an increase in the production of estradiol, close to ovulation, in sheep that used enalapril in the last three days of an FTAI protocol (COSTA et al., 2014). In another experiment, it was demonstrated, in goats, that the addition of the ACE inhibitor (enalapril) to the protocol of artificial insemination in fixed time (IATF), subcutaneously for 12 days, increased the rates of pregnancy, calving and twinning (FERNANDES NETO et al., 2018).

These results show a favorable effect of ACE inhibition on the efficiency of the FTAI protocol. However, there the need to verify whether this result may be related to RAS peptides. Therefore, the aim of this study was to verify the presence and location of the converting enzyme Ang II, Ang- (1-7) and angiotensin-converting enzyme 2 (ECA2) in goat ovarian tissue.

\section{MATERIALS AND METHODS}

The experimental and all procedures were carried after approved by the Animal Experimentation Ethics Committee of the UFPI, registry number 043/12.

In order to determine the presence and localization of Ang II, Ang-(1-7) and ACE2 in goat ovary, sixteen ovaries were collected from sixteen different non-pregnant goats in a local slaughterhouse (Teresina, Piauí, Brazil) in compliance with all regulations for animal care of the Ministry of Agriculture, Livestock and Food Supply. After collection, the goat ovarian fragments (measuring $0.5 \times 0.5 \mathrm{~cm}$ ) were fixed in $10 \%$ buffered formaldehyde and embedded in paraffin. Sections of $5-\mu \mathrm{m}$ thickness were mounted on gelatin-coated slides and stained using the avidin-biotin- peroxidase method with the Vectastain Universal Elite ABC Kit (Vector Laboratories, Burlingame, CA, USA) as previously described (HONORATO-SAMPAIO et al., 2012). Briefly, sections were dewaxed in xylene, rehydrated, and treated with $1 \%$ hydrogen peroxide in methanol for $30 \mathrm{~min}$ followed by normal equine blocking serum for $30 \mathrm{~min}$. The sections were incubated with primary antibodies at room temperature $\left(25^{\circ} \mathrm{C}\right)$ in a humid chamber for $2 \mathrm{~h}$ (HONORATO-SAMPAIO et al., 2012). The primary antibodies used were: rabbit polyclonal antiACE2 (1:500) (Abcam Inc., Cambridge, MA, USA), rabbit polyclonal anti-Ang-(1-7) (1:1000) and anti-Ang II $(1: 500)$ as previously described (SIMÓES AND SILVA et al., 2004). The slices were incubated with biotinylated universal antibody (1:50) plus normal horse serum (1:50) for $30 \mathrm{~min}$ followed by avidin-biotin peroxidase complex (1:50) for $30 \mathrm{~min}$.
The immunostaining was visualized with 3,3'-diaminobenzidine tetrahydrochloride (Sigma Chemical Co., St. Louis, MO, USA) and counterstained with Hematoxylin. Negative controls were obtained by preadsorption of primary antibody with antigens or by its replacement with nonimmune serum. (Figure $01-\mathrm{C}, \mathrm{F}$ and I). The images were taken using a 10x and 40x objetives.

\section{RESULTS}

This study reported the presence and location of Ang- (1-7), Ang II and ACE2 in goat ovary (Figure 01). Strong immunoreactivity was observed for Ang II, Ang- (1-7) and ACE2 in various ovary compartments, mainly in theca and luteal cells. For Ang II, strong immunoreactivity was observed in the cytoplasm of luteal cells and moderate one in the stroma.

For Ang-(1-7), strong immunoreactivity was observed in theca cells of antral follicles, corpus luteum and blood vessels, and mild immunoreactivity in the stroma and granulosa cells. In addition, strong immunoreactivity was observed in the oocyte cytoplasm in early antral follicles.

Also, as for Ang II, there was strong ACE2 immunoreactivity in cytoplasm luteal cells. In addition, moderate immunoreactivity was observed in ovarian stroma and theca cells of antral follicles. There was also mild ACE2 immunoreactivity observed in some granulosa cells.

\section{DISCUSSION}

This paper first reported the presence and localization of Ang (1-7), Ang II and ACE2 in goat ovarian. In other species, the presence of Ang-(1-7) was reported in prepubertal rabbits in the ovaries. Mainly in the stroma and oocytes of primary and secondary follicles (VIANA et al., 2011). In rat ovary cells, the presence of Ang- (1-7) and ACE 2 in the preovulatory follicles, particularly in the theca cells, has been reported. The presence of LH stimulated immunoreactivity for Ang-(1-7) in the theca and granulosa for both peptides (HONORATOSAMPAIO et al., 2012).

The peptides found in the goat ovaries in this study already have some direct or indirect activities related to reprocution demonstrated in other species. Thus, Ang II was involved in the stimulation of cellular proliferation and production of the vascular endothelial growth factor - VEGF in humans (ZHANG et al., 2019), essentials for follicular development. It was also involved in the vascularization and progesterone production in bovine corpus luteum, with PGF2 assistance (KOBAYASHI et al., 2002). Furthermore, Ang II has been associated with follicular atresia for activation of the cascade of caspase by the AT2 receptor, stimulating apoptosis of granulosa cells by changing the relationship with them or reducing the conversion of testosterone to estrogen (OBERMÜLLER et al., 2004). ACE2 is a homolog of classic ACE that forms Ang-(1-7) directly from Ang II and indirectly from Ang I (TIPNIS et al., 2000). The Ang-(1-7) increased in follicular 
Antral Follicle

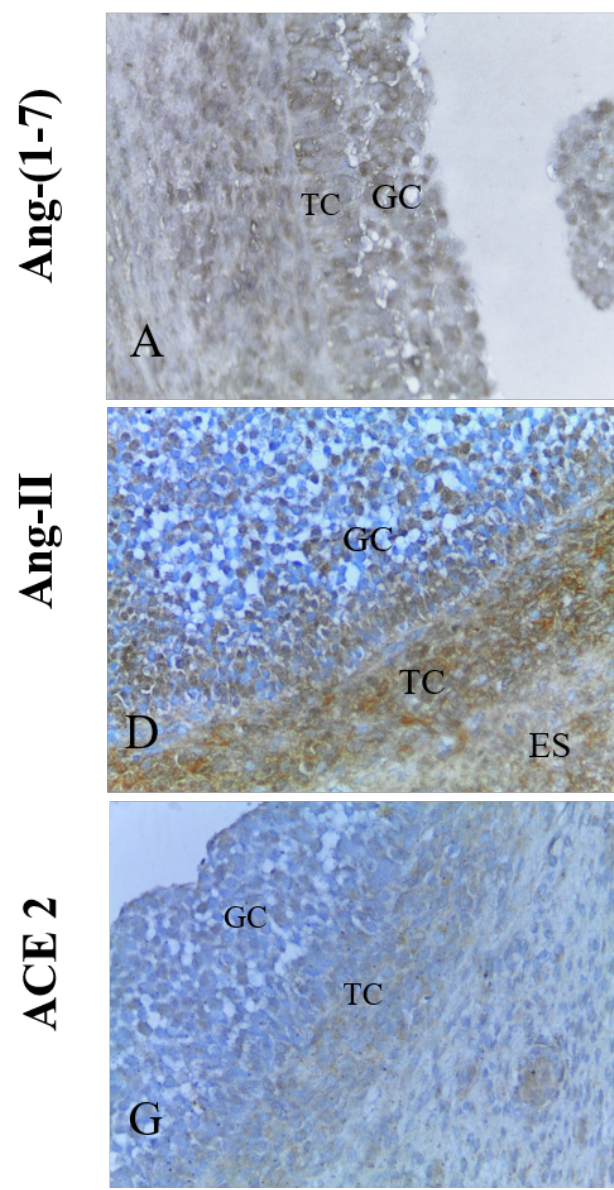

Corpus luteum

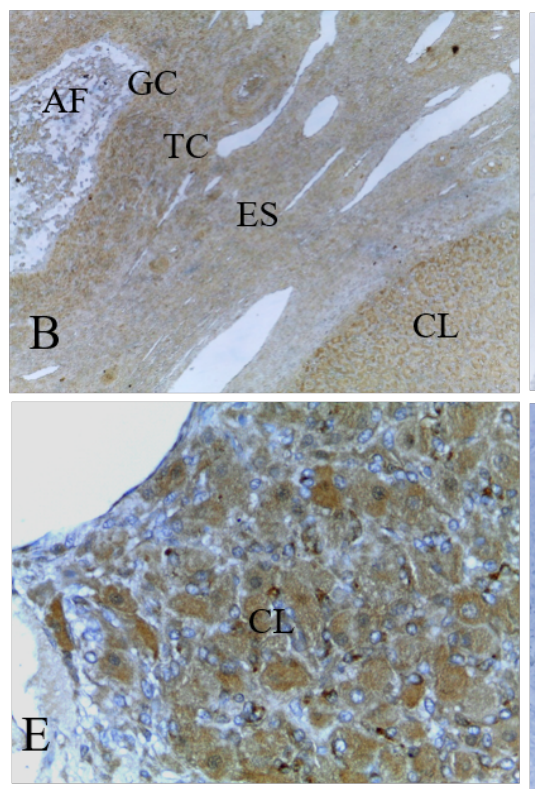

Control group*

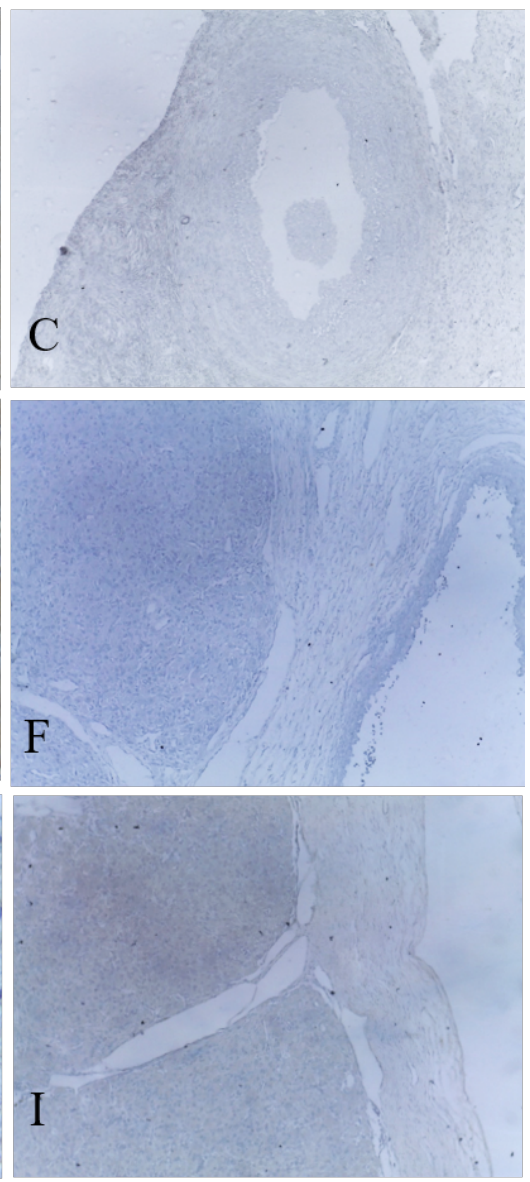

Figure 01. Immunolocalization of Ang-(1-7), Ang II and ACE2 in antral follicles and corpus luteum in goat ovary. GC: granulosa cells; TC: theca cells; ES: stroma; CL: corpus luteum; AF: antral follicle. * Control group was obtained without the primary antibody. Images A, D, E, $\mathrm{G}, \mathrm{H}$ taken using a $40 \mathrm{X}$ objective and images $\mathrm{B}, \mathrm{C}, \mathrm{F}$, I taken using a $10 \mathrm{X}$ objective.

fluid after the preovulatory LH surge (TONELLOTTO DOS SANTOS et al., 2012), suggesting an active participation in the ovulation process. Therefore, one can realize the importance of ACE for the transformation of Ang II to ANG (1-7) in the folliculogenesis and ovulation.

Ang-(1-7) hasf been reported for its anti-oxidant, antiinflammatory, anti-apoptotic and vasodilator effects (ALI et al., 2019; ANTONUCCI, et al., 2017). Anti-angiogenic effect happens through either the release of nitric oxide (MACHADO et al., 2001) or the reduction in vascular endothelial growth factor (SOTO-PANTOJA et al., 2009). This may indicate that the Ang-(1-7) would play an important role in helping luteolysis due to its anti-angiogenic role. It's possible to observe a strong immunoreactivity for ang II in the nucleus of lutein cells. Vaz and Silva et al (2012) reported the same staining and associated the non-specific marking of immunohistochemistry reactions to Ang-(1-7).

In the ovarian follicle, Ang-(1-7) has a role in the ovulatory process, stimulating estradiol production and enhancing ovulatory efficiency, promoting meiotic resumption in follicle-enclosed oocytes (SANTOS et al., 2018). Therefore, Ang(1-7) is an important physiological factor for follicular maturation and ovulation, as it is reinforced by its presence in the theca and granulosa cells found in the present study. It can thus be considered that the presence of these peptides in the ovarian tissue may support the assumption that increased rates of pregnancy, calving and twinning (FERNANDES NETO et al., 2018) may be related to some of these peptides.

\section{CONCLUSION}

The presence of Ang II, Ang- (1-7) and ACE2 was demonstrated in goat ovaries, notably in theca and luteal cells and this distribution demonstrates a possible action in follicular and luteal function, pointing to the need for more studies in this area.

\section{ACKNOWLEDGEMENTS}

The authors would like to acknowledge Conselho Nacional de Desenvolvimento Científico e Tecnológico (CNPq) and Coordenação de Aperfeiçoamento de Pessoal de Nível Superior (CAPES) for research support. 


\section{REFERENCES}

ALDERMAN, M. H. Renin Angiotensin System and the Heart. Circulation, v. 110, n. 9, p. e496-e497, 2004.

ALI, F. F.; AHMED, A. F.; ALI, D. M. E. Underlying mechanisms behind the protective effect of angiotensin (1-7) in experimental rat model of ovarian ischemia reperfusion injury. Life Sciences, v. 235, p. 1-9, 2019.

ANTONUCCl, E. et al. Angiotensin II in refractory septic shock. Shock, v. 47, n. 5, p. 560-566, 2017.

COSTA, A. P. R. et al. Angiotensin-(1-7): a novel peptide in the ovary. Endocrinology, v. 144, n. 5, p. 1942-1948, 2003.

CHAPPELL, M. C. et al. Metabolism of angiotensin-(1-7) by angiotensin-converting enzyme. Hypertension, v. 3l, n. l, p. 362-367, 1998.

COSTA, A. S. et al. Inhibition of angiotensin-converting enzyme increases oestradiol production in ewes submitted to oestrous synchronization protocol. Reproduction in Domestic Animals, v. 49, п. 5, p. 53-55, 2014.

FERNANDES NETO, V.P. et al. ACE inhibition in goats under fixedtime artificial insemination protocol increases the pregnancy rate and twin births. Reprodction in Domestic Animals, v. 53, n. 4, p. 1006-1008, 2018.

GRACE, J. A. et al. Update on new aspects of the rennin-angiotensin system in liver disease: clinical implications and new therapeutic options. Clinical Science, v. 123, p. 225-239, 2012.

HONORATO-SAMPAIO, K. V. et al. Evidence that angiotensin-(1-7) is an intermediate of gonadotropin-induced maturation in the rat preovulatory follicle. Experimental Physiology, v. 97, n. 5, p. 642-650, 2012.

KOBAYASHI, S. et al. Intraluteal release of angiotensin II and progesterone In vivo during corpora lutea development in the cow: Effect of vasoactive peptides. Biology of Reproduction, v. 66, n. 1, p. 174-179, 2002.

KUMAR, R. et al. The intracrine reninangiotensin system. Clinical Science, v. 123, n. 5, p. 273-284, 2012.
MACHADO, R. D. P.; SANTOS, R. A. S.; ANDRADE, S. P. Mechanisms of angiotensin-(1-7)-induced inhibition of angiogenesis. American Journal of Physiology-Regulatory, Integrative and Comparative Physiology, v. 280, n. 4, p. R994-R1000, 2001.

OBERMÜLLER, N. et al. Immunohistochemical and mRNA Localization of the angiotensin ii receptor subtype 2 (at2) in follicular granulosa cells of the rat ovary. Journal of Histochemistry \& Cytochemistry, v. 52, п. 4, p. 545-548, 2004.

SANTOS, R. A. S. The ace2/angiotensin-(1-7)/mas axis of the reninangiotensin system: focus on angiotensin-(1-7). Physiological Reviews, v. 98, p. 505-553, 2018.

SIMOES-AND-SILVA, A. C. et al. The renin angiotensin system in childhood hypertension: selective increase of angiotensin-(1-7) in essential hypertension. The Journal of Pediatric, v. 145, p. 93-98,2004.

SOTO-PANTOJA, D. R. etal.Angiotensin-(1-7) inhibits tumorangiogenesis in human lung cancer xenografts with a reduction invascularendothelial growthfactor.MolecularCancerTherapeutics, v. 8, n. 6, p.1676-1683, 2009.

TIPNIS, S. R. et al. A human homolog of angiotensin-converting enzyme. Cloning and functional expression as a captopril-insensitive carboxypeptidase. The Journal of Biological Chemistry, v. 275, p. 33238-33243, 2000.

TONELLOTTO DOS SANTOS, J.; FERREIRA, R.; GASPERIN, B. G. Molecular characterization and regulation of the angiotensinconverting enzyme type 2 /angiotensin-(1-7)/MAS receptor axis during the ovulation process in cattle. Journal of the ReninAngiotensin-Aldosterone System, v. 13, p. 91-98, 2012.

VAZAND SILVA, J. et al. Tissue specific localization of angiotensin-(1-7) and its receptor Mas in the uterus of ovariectomized rats. Journal of Molecular Histology, v. 43, p. 597-602, 2012.

VIANA, G. E. N. et al. Angiotensin-(1-7) induces ovulation and steroidogenesis in perfused rabbit ovaries. Experimental Physiology, v. 96, п. 9, p. 957-965, 2011.

ZHANG, Q. et al. Angiotensin II promotes ovarian cancer spheroid formation and metastasis by upregulation of lipid desaturation and suppression of endoplasmic reticulum stress. Journal of Experimental \& Clinical Cancer Research, v. 38, n. 116, p. 1-18, 2019. 